\title{
The AD/HD Syndrome as a Group of Biological Disorders
}

\author{
Anders Ziegler1, Magne Nødland², Dag Tveiten1, Karl L. Reichelt1,3* \\ ${ }^{1}$ Lab 1, No. 1337, Sandvika, Norway \\ ${ }^{2}$ Stavanger, Norway \\ ${ }^{3}$ University of Oslo, Oslo, Norway \\ Email: "k.I.reichelt@medisin.uio.no
}

Received 2 December 2015; accepted 2 March 2016; published 8 March 2016

Copyright (C) 2016 by authors and Scientific Research Publishing Inc.

This work is licensed under the Creative Commons Attribution International License (CC BY). http://creativecommons.org/licenses/by/4.0/

(c) (i) Open Access

\begin{abstract}
Problem: There is a need to collect the many and varied data on AD/HD (Attention deficit hyperactivity disorder) into a meaningful overview. Method: Based on peer reviewed and published data as well as own research we try to make sense of the physiological mechanisms resulting in the relevant symptoms. Conclusion: AD/HD clearly has a genetic disposition, but as with many other genetic syndromes, the resulting proteomics must be stressed to become manifest as disease/ disorder. A common trait in the different etiologies is lower arousal.
\end{abstract}

\section{Keywords}

AD/HD, Arousal, Genetics, Peptides, Diet, PUFA (Poly Unsaturated Fatty Acids), Monamines

\section{Introduction}

$\mathrm{AD} / \mathrm{HD}$ is mainly a disorder of childhood, but may often persist into adulthood [1] [2]. According to DSM V it should have onset before the age of five, and is marked by symptoms as outlined in Table 1. Patients are noticeable by the inability to concentrate over time in cognitive tasks, easy to distract, poor impulse control and excessive motor activity. The prevalence used to be 3\% - 7\% with great regional variance, but reports indicate much higher levels today [2]. Prognosis is varied, and some apparently grow out of it, while others retain their troubled behavior. CNS stimulants have a clear cut calming effect, but the effect on learning is uncertain (see below). A genetic disposition is found and various interventions and research data found point to possible mechanisms causing the AD/HD symptoms (see the following). We here present a biological view of $\mathrm{AD} / \mathrm{HD}$ and explain wherefore this is a necessary foundation for intervention and effective therapy.

${ }^{*}$ Corresponding author. 


\section{Method}

\subsection{Genetics}

A very strong genetic disposition has been found [3]-[6]. Genetics means chemistry, if not it is not genetic. Even epi-genetics involve chemistry, which therefore must be the priority area of research and intervention. A classic example of a genetic disorder is Phenylketonuria where an overload of phenylalanine (F) relative to enzyme capacity of phenylalanine dehydrogenase causes increase in the amino acid (F), secondary metabolites and cause mental retardation. The use of extremely low $\mathrm{F}$ diet prevents this disaster from happening. Interestingly where there is some residual effect of the enzyme due to some less lethal mutations, increase in critical vitamins (acting as cofactors) can also prevent $\mathrm{F}$ accumulation. This is explained by Ames 2002 [7].

\subsection{Diagnosis}

Diagnosis is to day mostly done clinically based on symptoms. This is a threat to all double blind studies, since different etiologies may well be subsumed under the same diagnosis. This means that if there are several different causes, double blind studies have a poor chance of having experimental and control groups equal [8]. That these two groups should be the same is a necessary condition for doing a double blind study (Table 1).

Comparing the handwriting before and after treatment with Ritalin, shows the lack of care to details before and increased care after the drug [9]. Excess drug is seen to cause miniaturized hand writing. In the absence of galvanic skin conductance this may be a useful tool.

The diagnosis is not easy since a visit to the MD or GP may be fear inducing, which tends to normalize the behavior. The report by parents, teachers and peers is often helpful. Many epileptic children on anti-epileptic drugs that are mainly inhibitory towards neurons, often show a syndrome similar to AD/HD. This reinforces the low arousal state described by Eysenck for extreme extraversion [10].

\subsection{Physiology}

The decreased galvanic skin conduction in the palms of the hand reflects lower Central Nervous arousal. Therefore faster than normal habituation to sensory stimuli is found [11] [12]. Hypo-thyroid children where the CNS is inhibited, tend to show similar behavioral changes. The AD/HD children often show remarkable innovative ability (especially pranks), and if they learn to direct their distractibility a valuable asset.

The CNS lower arousal is confirmed by the glucose uptake data presented for the brain in ADHD [13]-[15]. People who have reduced Thyroid hormone receptor activity [16], which again would reduce neuronal activation, show hyperactivity and attention problems. Mercury (Hg), lead (Pb) and Aluminium ( $\mathrm{Al})$ [17] that interfere with CNS mitochondrial energy production may also cause hyperactivity. $\mathrm{Zn}$ is a cofactor for some 72 enzymes and seems decreased in a sub-group [18].

The genetic disposition seems to be dependent on monoamine transporter differences for noradrenaline, do-

Table 1. Lists the main diagnostic elements.

\begin{tabular}{|c|c|}
\hline Symptom or sign & Comment \\
\hline Early onset & Usually before the age of 5 \\
\hline Hyperactive & Especially when self-employed, fidgeting, and restless \\
\hline Lack of concentration & Especially on cognitive tasks over time \\
\hline Impulsive & Acting without considering consequences \\
\hline Social isolation & Rejected by peers due to impulsivity, aggression and inability to await turn \\
\hline Dyslexia & Found in up to $30 \%$ \\
\hline Attention problems & Easily distracted from tasks \\
\hline Aggression & Caused by frustration at work and play \\
\hline Low galvanic skin response & Low arousal \\
\hline Fast habituation & To sensory inputs \\
\hline EEG changes & Common. \\
\hline
\end{tabular}


pamine and serotonin (see later). Thus the mainly attention dominated syndrome is related to noradrenaline, while the more impulsive, hyperactive to dopamine [2]. Also the choline transporter has been related to a balanced state for all the three areas mentioned [19].

\subsection{Drugs}

Much of the superior cortex is repressive towards more ancient brain structures. Alcohol is generally inhibitory towards neurons, and worsens the hyperkinetic state with increased aggression, before they are overwhelmed by sleep. CNS arousing medication tends to normalize the hyperactivity and cause less aggression and better focus [20]-[22]. However, the academic performance usually does not improve over time to the same extent [22]. For parents the pacifying effect of Ritalin is often felt as a tremendous relief. Both amphetamine and Ritalin have side effects that may be serious [23]. Thus growth inhibition is often seen. A series of papers point to permanent changes in midbrain synapses and transmitters in animal studies [24] [25] and in human patients [26]-[28].

\subsection{Chemical Changes Found}

One of the most reproducible data is increased platelet serotonin [29] [30]. Most monoamines show hormetic dose reponse curves, hence evaluation of transport protein changes found are difficult to evaluate. A tetra- peptide from casein that increased the uptake of serotonin (5-HT) into platelets has been found [31] and sometimes also a tripeptide found in autism from reelin [32]. Decreased level of serotonin should be found in the synaptic cleft, which would result in increased aggressiveness, faster habituation and impulsivity [30]. Generally increased level of urine peptides has also been found by Hole et al. [33].

It has been proposed that the mainly attention dominated subtype is related to the noradrenaline (NA) transporter, while the impulsive, hyperactive type by the dopamine transporter [2]. Also the choline transporter has been found relevant to a mixed type [19]. Possibly common to these data is that opioids from food proteins can stimulate DA (Dopamine) and 5-HT uptake into synaptosomes [34] in the striatum. The DA subtype may respond best to Ritalin while the NA subtype to Strattera [2].

Also decreased levels of Zink [35] and increased levels of uric acid [36] [37] related to aggressiveness have been reported. Exposure to $\mathrm{Pb}$ (lead) and mercury (Hg) also prenatally [38] apparently can be causative factors, and are extensive inhibitors of SH enzymes and mitochondrial activity, with reduced neuronal energy availability. Aluminum inhibits the Citric acid cycle directly [17]. The level of activity in the CNS is especially dependent on available energy. Decreased available energy ought to cause decreased arousal.

\subsection{Dietary Intervention}

Published papers are describing a) effects of certain food proteins, b) role of unsaturated fatty acids, c) dependence on food additives and d) Effect of metal ion corrections.

1) Dietary intervention has been mainly done by removing most foods and reintroducing these one by one [39]-[46]. Looking over the tables, milk casein and gluten (glutenin and gliadins) tends to dominate the overall picture. These are the proteins that can release opioids and also a 5-HT uptake stimulator [31]. The effect seems rather convincing especially since exposing the children to eliminated foods induce EEG changes in AD/HD patients [47]. On a casein free diet we have followed patients up to five years. We found significant effects on the total peptide level and Childhood behavior checklist at the start and after five years with p values of 0.012 for CBCL and 0.018 for decrease in peptide levels [46]. In Table 2 the decrease in rating scale carried out by parents and teachers after one and five years on a milk free diet, and also the decrease in total UV215 nm substances eluting on the HPLC after hippuric acid is shown. Most of these have been shown to be peptides [33]. The lack of normality of the data after one year and difference in teacher to parents rating probably reflects the great differences in speed of recovery.

Table 2. Decrease in rating scale and UV $215 \mathrm{~nm}$ material eluting after hippuric acid that are mostly peptides.

\begin{tabular}{cccccc}
\hline Cohort & $\mathrm{n}$ & $\begin{array}{c}\text { Teachers } \\
\text { Rating } \pm \text { s.d. }\end{array}$ & $\begin{array}{c}\text { Parents } \\
\text { Rating } \pm \text { s.d. }\end{array}$ & $\begin{array}{c}\text { Decrease in UV215 nm } \\
\text { Material } \pm \text { s.d. }\end{array}$ \\
\hline After 1 year & 24 & $-66.75 \pm 12.54$ & $-73.17 \pm 7.48$ & $-546.78 \pm 176.59$ & Not normally distributed \\
After 5 years & 8 & $-72.46 \pm 5.59$ & $-70.42 \pm 6.02$ & $-722.73 \pm 312.62$ & Normally distributed \\
\hline
\end{tabular}


We used CBCL: Child Behavior Check List and UV 215 nm area under the curve eluting after Hippuric acid. The teacher and parent checklist are different after one year using pairwise non-parametric statistics with $\mathrm{p}=$ 0.01. After five years the data were normally distributed, hence paired t test gave a $\mathrm{p}=0.59$, not significant (for method see ref. 46).

2) Fatty acids (omega-3 especially)

A modest effect on a meta-analysis [48] has been found. However, as can be seen from the many factors involved in the ADHD etiology, the data from more selected cases seem better [49]-[52]. Increasing the fluidity of membranes would allow enzymes and receptors associated with the membranes to take on less restricted configurations and possibly improve their efficacy.

\section{3) Food additives}

This was first suggested by Feingold. However, allergy could not be found related to these compounds such as benzoic acid, salicylates and food colorings (often azides). They are all, however, inhibitory to hydrolytic enzymes and hence used for preserving food as does the bees with their honey. The breakdown of peptides and other low MW compounds can thus be inhibited, in some cases deleterious to the AD/HD state. Clearly these compounds have effects on at least a subgroup [53]-[57].

\section{4) Mineral disturbances}

Both $\mathrm{Hg}$ and $\mathrm{Pb}$ and $\mathrm{Al}$ cause inhibition of mitochondrial energy production and therefore also neuronal activity through the decrease in energy available. Single case studies sometimes show remarkable success of supplying $\mathrm{Zn}$ [58] and chelating out $\mathrm{Hg}$ and $\mathrm{Pb}$.

\subsection{Safeguards against Malnutrition: On Diet}

On diet our group routinely employs the following to safeguard against malnutrition:

1) Cod liver oil (spoon full) (possibly+ omega-3);

2) $500 \mathrm{mg}$ calcium with $\mathrm{D}$ vitamin daily;

3) 200 mg C vitamin daily;

4) $200 \mathrm{mg}$ Acetyl-cystein daily (increases glutathione in cells);

5) every 2nd day: Multivitamins with trace minerals and $\mathrm{Mg}$.

Length and weight should be routinely monitored.

\section{Conclusion}

It seems that there are several etiologies in AD/HD and ADD since very different compounds are involved. There is the possibility that they all end up in a common final path resulting in inhibition of the CNS arousal system. There seems to be faster inhibition of neuronal activity or decreased activation. However, they may also be separate and direct causes. Given the risk of misuse of drugs and the clearly harmless effect of diet + supplements of vitamins and trace minerals, fatty acids like omega-3 and $\mathrm{Zn}$, these alternatives should be considered more extensively in the treatment of AD/HD. Double blind studies without taking the different etiologies into account are close to senseless.

\section{References}

[1] APA (2010) Attention Deficit Hyperactivity Disorder in Diagnostic and Statistical Manual of Mental Disorders IV. American Psychiatric Association, Arlington.

[2] Gromisch, E.S. (2015) Neurotransmitters Involved in ADHD. Psych Central.

[3] Safer, D.J. (1973) A Familial Factor at Minimal Brain Dysfunction. Behavior Genetics, 3, 175-186. http://dx.doi.org/10.1007/BF01067657

[4] Thayer, A., Hervas, A. and McGuffen, P. (1995) Childhood Hyperactivity Scores Are Highly Heritable and Show Sibling Amplification Effects: Twin Study Evidence. Behavior Genetics, 25, 537-544. http://dx.doi.org/10.1007/BF02327577

[5] Hechtman, I. (1994) Genetic and Neurobiological Aspects of Attention Deficit Hyperactive Disorder: A Review. Journal of Psychiatry and Neuroscience, 19, 193-201.

[6] Zametkin, A.J. (1995) Attention-Deficit Disorder. Born to Be Hyperactive? JAMA, 273, 1871-1874. http://dx.doi.org/10.1001/jama.1995.03520470079036 
[7] Ames, B.N., Elson-Schwab, I. and Silver, E.A. (2002) High Dose Vitamin Therapy Stimulates Variant Enzymes with Decreased Coenzyme Binding Affinity (Increased K(m)): Relevance to Genetic Disease and Polymorphism. The American Journal of Clinical Nutrition, 75, 616-653.

[8] Reichelt, Y. and Reichelt, K.-L. (2015) Problems with Double Blind in Medicine. Open Journal of Psychiatry, 5, 204-206. http://dx.doi.org/10.4236/ojpsych.2015.52024

[9] Lerer, R.J., Lerer, M.P. and Artner, J. (1977) The Effects of Methyl-Phenidate on the Handwriting of Children with Minimal Brain Dysfunction. Journal of Pediatrics, 91, 127-132.

[10] Eysenck, H.L. (1970) The Structure of Human Personality. 3rd Edition, Methuen, London.

[11] Kløve, H. and Hole, K. (1979) The Hyperkinetic Syndrome. Criteria for Diagnosis. In: Tritees, R.L., Ed., Hyperactivity in Children. Etiology, Measurement and Treatment Implications, University Park Press, Baltimore, 121-136.

[12] Satterfield, J.H. and Dawson, M.E. (1971) Electrodermal Correlates of Hyperactivity in Children. Psychophysiology, 8, 191-197. http://dx.doi.org/10.1111/j.1469-8986.1971.tb00450.x

[13] Zametkn, A.J., Nordahl, T.E., Gross, M., King, A.C., Semple, W.E., Ramsey, J., Hamburger, S. and Cohen, R.M. (1990) Cerebral Glucose Metabolism in Adults with Hyper-Activity of Childhood Onset. The New England Journal of Medicine, 323, 1361-1366. http://dx.doi.org/10.1056/NEJM199011153232001

[14] Matochik, J.A., Liebenauer, L.L., King, A.C., Szynanski, H.V., Cohen, R.M. and Zanetta, A.J. (1994) Cerebral Glucose Metabolism in Adults with Attention Deficit Hyperactivity Disorder after Chronic Stimulant Treatment. The American Journal of Psychiatry, 151, 658-664. http://dx.doi.org/10.1176/ajp.151.5.658

[15] Ernst, M., Liebenauer, L.L., King, A.C., Fitzgerald, G.A., Cohen, R.M. and Zanetta, A.J. (1994) Reduced Brain Metabolism in Hyperactive Girls. Journal of the American Academy of Child \& Adolescent Psychiatry, 33, 858-868. http://dx.doi.org/10.1097/00004583-199407000-00012

[16] Hauser, P., Zametkin, A.J., Maryinez, P., Vitello, B., Matochik, J.A., Mixson, A.J. and Weintraub, B.D. (1993) Attention Deficit-Hyperactivity Disorder in People with Generalized Resistance to Thyroid Hormone. The New England Journal of Medicine, 328, 997-1001. http://dx.doi.org/10.1056/NEJM199304083281403

[17] Mullen, N. and Yasko, A. (2013) Aluminum Toxicity in Mitochondrial Dysfunction and ASD. Journal of Autism, 2, 23-29.

[18] Arnold, L.E., Bozzio, H., Hallway, J., Cook, A., DiSilvestro, R.A., Bozzolo, D.R., et al. (2005) Serum Zinc Correlates with Parent- and Teacher-Rated Inattention in Children with Attention-Deficit/Hyperactivity Disorder. Journal of Child and Adolescent Psychopharmacology, 15, 628-636. http://dx.doi.org/10.1089/cap.2005.15.628

[19] English, B.A., Hahn, M.K., Gizer, I.P., et al. (2009) Choline Transporter Gene Variation Is Associated with Attention-Deficit Hyperactivity Disorder. Journal of Neurodevelopmental Disorders, 1, 252-263.

[20] Pelham, W.E., Bender, M.E., Caddewell, J., Booth, S. and Moorer, S.H. (1985) Methylphenidate and Children with Attention Deficit Disorder: Dose Effects on Classroom Academic and Social Behavior. JAMA Psychiatry, 42, 948-952. http://dx.doi.org/10.1001/archpsyc.1985.01790330028003

[21] Rapport, M.D., Demey, C., DuPaul, G.J. and Gardner, M.J. (1994) Attention Deficit Disorder and Methylphenidate: Normalization Rates, Clinical Effectiveness, and Response Prediction in 76 Children. Journal of the American Academy of Child \& Adolescent Psychiatry, 33, 882-893. http://dx.doi.org/10.1097/00004583-199407000-00015

[22] Epstein, J.N., Conners, C.K., Harvey, A.S., Tonev, S.T., Arnold, L.E., Abikoff, H.B., et al. (2006) Assessing Medication Effects in the MTA Study Using Neuropsychological Outcomes. Journal of Child Psychology and Psychiatry, 47, 446-456. http://dx.doi.org/10.1111/j.1469-7610.2005.01469.x

[23] Nissen, S.E. (2006) ADHD Drugs and Cardiovascular Risk. The New England Journal of Medicine, 354, $1445-1448$. http://dx.doi.org/10.1056/NEJMp068049

[24] Williams, M.T., Brown, RW. and Vorhees, C. (2004) Neonatal Methamphetamine Administration Induces RegionSpecific Long-Term Neuronal Morphological Changes in the Rat Hippocampus, Nucleus Accumbens and Parietal Cortex. European Journal of Neuroscience, 19, 3165-3170. http://dx.doi.org/10.1111/j.0953-816X.2004.03405.X

[25] Brandon, C.L., Marinelli, M. and White, F.J. (2003) Adolescent Exposure to Methylphenidate Alters the Activity of Rat Midbrain Dopamine Neurons. Biological Psychiatry, 54, 1338-1344. http://dx.doi.org/10.1016/S0006-3223(03)00787-X

[26] Carlezon, W.A., Mague, S.D. and Andersen, S.L. (2003) Enduring Behavioral Effects of Early Exposure to Methylphenidate in Rats. Biological Psychiatry, 54, 1330-1337. http://dx.doi.org/10.1016/j.biopsych.2003.08.020

[27] Hejhtz, R.D., Kolb, B. and Forsberg, H. (2003) Can a Therapeutic Dose of Amphetamine during Pre-Adolescence Modify the Pattern of Synaptic Organization in the Brain? European Journal of Neuroscience, 18, 3394-3399. http://dx.doi.org/10.1046/j.0953-816X.2003.03067.x

[28] Forsberg, H., Fernel, E., Waters, S., Waters, N. and Tedroff, J. (2006) Altered Pattern of Brain Dopamine Synthesis in 
Male Adolescents with Attention Deficit Hyperactivity Disorder. Behavioral and Brain Functions, 2, 40-47. http://dx.doi.org/10.1186/1744-9081-2-40

[29] Rogeness, G.A., Javors, M.A. and Pliska, S.R. (1992) Neurochemistry and Child and Adolescent Psychiatry. Journal of the American Academy of Child \& Adolescent Psychiatry, 31, 765-781. http://dx.doi.org/10.1097/00004583-199209000-00001

[30] Halperin, J.M., Sharam, V., Siever, L.J., Schwartz, S.T., Motier, K., Wonnell, G. and Newcorn, J.A. (1994) Serotoninergic Function in Aggressive and Nonaggressive Boys with Attention Deficit Hyperactivity Disorder. The American Journal of Psychiatry, 151, 243-248. http://dx.doi.org/10.1176/ajp.151.2.243

[31] Liu, Y. and Reichelt, K.L. (2001) A Serotonin Uptake-Stimulating Tetra-Peptide Found in Urines from ADHD Children. The World Journal of Biological Psychiatry, 2, 144-148. http://dx.doi.org/10.3109/15622970109026800

[32] Pedersen, O.S., Liu, Y. and Reichelt, K.L. (1999) Serotonin Uptake Stimulating Peptide Found in Plasma of Normal Individuals and in Some Autistic Urines. The Journal of Peptide Research, 53, 641-646. http://dx.doi.org/10.1034/j.1399-3011.1999.00058.x

[33] Hole, K., Lingjaerde, O., Mørkrid, L., Bøler, J.B., Sælid, G., Didericksen, J., Ruud, E. and Reichelt, K.L. (1988) Attention Deficit Disorders: A Study of Peptide-Containing Urinary Complexes. Journal of Developmental Behavioral Pediatrics, 9, 205-212. http://dx.doi.org/10.1097/00004703-198808000-00005

[34] Hole, K., Bergslien, A.A., Jørgensen, H., Berge, O.G., Reichelt, K.L. and Trygstad, O.E. (1979) A Peptide-Containing Fraction in the Urine of Schizophrenic Patients which Stimulates Opiate Receptors and Inhibits Dopamine Uptake. Neuroscience, 4, 1883-1893. http://dx.doi.org/10.1016/0306-4522(79)90062-9

[35] Toren, P., Elder, S., Sela, B.A., Wolmer, L., et al. (1996) Zinc Deficiency in Attention-Deficit Hyperactivity Disorder. Biological Psychiatry, 40, 1308-1310. http://dx.doi.org/10.1016/S0006-3223(96)00310-1

[36] Borrera, V.C.M., Ruiz, Z.R. and Dunlap, W.P. (1988) Uric Acid: A Participating Factor in the Symptoms of Hyperactivity. Biological Psychiatry, 24, 344-347. http://dx.doi.org/10.1016/0006-3223(88)90205-3

[37] Spitz, R.T., Hillbrand, M. and Foster, H.G. (1976) Uric Acid Levels and Severity of Aggression. Psychological Reports, 76, 130. http://dx.doi.org/10.2466/pr0.1995.76.1.130

[38] Sagiv, S.K., Thurston, S.W., Bellinger, D.C., Amarasiriwardena, C. and Korrick, S.A. (2012) Prenatal Exposure to Mercury and Fish Consumption during Pregnancy and Attention-Deficit/Hyperactivity Disorder-Related Behavior in Children. Archives of Pediatrics and Adolescent Medicine, 166, 1123-1131. http://dx.doi.org/10.1001/archpediatrics.2012.1286

[39] Egger, J., Carter, C.M., Graham, P.J., Guley, D. and Soothill, J.F. (1985) Controlled Trial of Oligoantigenic Treatment in the Hyperkinetic Syndrome. The Lancet, 325, 540-545. http://dx.doi.org/10.1016/S0140-6736(85)91206-1

[40] Egger, J., Stolla, A. and McEwen, L.M. (1992) Controlled Trial of Hyposensitisation in Children with Food-Induced Hyperkinetic Syndrome. The Lancet, 339, 1150-1153. http://dx.doi.org/10.1016/0140-6736(92)90742-L

[41] Kaplan, S.J., McNicol, J., Conte, R.A. and Moghadam, H.K. (1989) Dietary Replacement in Preschool-Aged Hyperactive Boys. Pediatrics, 83, 7-17.

[42] Carter, C.M., Urbanowicz, M., Hemsley, R., Mantilla, L., Strobel, S., Graham, P.J. and Taylor, E. (1993) Effects of a Few Food Diet in Attention Deficit Disorder. Archives of Disease in Childhood, 69, 564-568. http://dx.doi.org/10.1136/adc.69.5.564

[43] Schmidt, M.H., Möcks, P., Lay, B., Eisert, H.-G., Fritz-Sigmund, D., Marcus, A. and Musaeus, B. (1997) Does Oligoantigenic Diet Influence Hyperactivity/Conduct-Disordered Children-A Controlled Trial. European Child \& Adolescent Psychiatry, 6, 88-95.

[44] Pelsser, L.M.J., Frankena, K., Toorman, J., Savekoul, H.F.J., Pereira, R.R. and Buitelaar, J.K. (2009) A Randomised Controlled Trial into the Effects of Food on ADHD. European Child \& Adolescent Psychiatry, 18, 12-19. http://dx.doi.org/10.1007/s00787-008-0695-7

[45] Pelsser, L.M.J., Frankena, K., Toorman, J., Savelkoul, H.F., Dubois, A.E., Pereira, R.R., Haagen, T.H., Romela, N.N. and Buitelaar, J.H. (2011) Effects of a Restricted Elimination Diet on the Behaviour of Children with Attention-Deficit Hyperactivity Disorder (INCA Study): A Randomised Controlled Trial. The Lancet, 377, 494-503. http://dx.doi.org/10.1016/S0140-6736(10)62227-1

[46] Reichelt, K.L., Nödland, M., Fosse, K. and Knivsberg, A.-M. (2008) AD/HD: Possible Diagnosis and Treatment. Journal of Special Education and Rehabilitation, 9, 63-95.

[47] Uhlig, I., Merkenschlager, A., Brandmaier, R. and Egger, J. (1997) Topographic Mapping of Brain Electrical Activity in Children with Food-Induced Attention Deficit Hyperactivity Disorder. European Journal of Pediatrics, 156, 557561. http://dx.doi.org/10.1007/s004310050662

[48] Bloch, M.H. and Qawasmi, A. (2011) Omega-3 Fatty Acid Supplementation for the Treatment of Children with Attention-Deficit/Hyperactivity Disorder Symptomatology: Systematic Review and Meta-Analysis. Journal of the American 
Academy of Child and Adolescent Psychiatry, 50, 991-1000. http://dx.doi.org/10.1016/j.jaac.2011.06.008

[49] Hallahan, B. and Garland, M.R. (2004) Essential Fatty Acids and Their Role in the Treatment of Impulsivity Disorders. Prostaglandins, Leukotrienes and Essential Fatty Acids, 71, 211-216. http://dx.doi.org/10.1016/j.plefa.2004.03.006

[50] Hamazaki, H.S., Hamazaki, T. and Terasawa, K. (2004) The Effect of Docoahexanoic Acid-Containing Food Administration on Symptoms of Attention-Deficit/Hypeactivity Disorder-A Placebo-Controlled Double-Blind Study. European Journal of Clinical Nutrition, 58, 838. http://dx.doi.org/10.1038/sj.ejcn.1601888

[51] Gustafsson, P.A., Birberg-Thornberg, U., Duchén, K., Landgren, M., Malmberg, K., Pelling, H., Strandvik, B. and Karlsson, T. (2010) EPA Supplementation Improves Teacher-Rated Behaviour and Oppositional Symptoms in Children with ADHD. Acta Paediatrica, 99, 1540-1549. http://dx.doi.org/10.1111/j.1651-2227.2010.01871.x

[52] Stevens, L.J., Kuczek, T., Burgess, J.R., Hurt, E. and Arnold, L.E. (2001) Dietary Sensitivity and ADHD Symptoms: Thirty-Five Years of Research. Clinical Pediatrics, 50, 279-293. http://dx.doi.org/10.1177/0009922810384728

[53] Boris, M. and Mandel, F.S. (1994) Foods and Additives Are Common Causes of the Attention Deficit Hyperactive Disorder in Children. Annals of Allergy, 72, 462-468.

[54] Connors, C.K., Goyette, C.H., Sothwick, D.A., Lees, J.M. and Andrulonis, P.A. (1978) Food Additives and Hyperkinesis: A Controlled Double-Blind Experiment. Pediatrics, 58,154-166.

[55] Weiss, B., Williams, J.H., Margen, S., Abrams, B., Caan, B., Citron, L.J., et al. (1980) Behavioral Responses to Artificial Food Colors. Science, 207, 1487-1489. http://dx.doi.org/10.1126/science.7361103

[56] Swanson, J.M. and Kinsbourne, M. (1980) Food Dyes Impair Performance of Hyperactive Children on a Laboratory Learning Test. Science, 207, 1485-1487. http://dx.doi.org/10.1126/science.7361102

[57] McCann, D., Barrett, A., Cooper, A., Crumpier, D., Dalen, L., et al. (2007) Food Additives and Hyperactive Behaviour in 3-Year-Old and 8/9-Year-Old Children in the Community: A Randomised, Double-Blinded, Placebo-Controlled Trial. The Lancet, 370, 1560-1567. http://dx.doi.org/10.1016/S0140-6736(07)61306-3

[58] Akhonzadeh, S., Mohammadi, M.-R. and Khademi, M. (2004) Zinc Sulfate as an Adjunct to Methylpehnidate for the Treatment of Attention Deficit Hyperactivity Disorder in Children: A Double Blind and Randomized Trial. BMC Psychiatry, 4, 9-14. http://dx.doi.org/10.1186/1471-244X-4-9 